\title{
ADAMTS1-mediated targeting of TSP-1 by PPAR $\delta$ suppresses migration and invasion of breast cancer cells
}

\author{
Sun Ah Ham ${ }^{1}$, Taesik Yoo ${ }^{1}$, Won Jin Lee ${ }^{1}$, Jung Seok Hwang ${ }^{1}$, Jinwoo Hur ${ }^{1}$, Kyung \\ Shin Paek ${ }^{2}$, Dae-Seog Lim ${ }^{3}$, Sung Gu Han ${ }^{1}$, Chi-Ho Lee ${ }^{1}$ and Han Geuk Seo ${ }^{1}$ \\ ${ }^{1}$ Sanghuh College of Life Sciences, Konkuk University, Seoul 05029, Korea \\ ${ }^{2}$ Department of Nursing, Semyung University, Jechon 27136, Korea \\ ${ }^{3}$ Department of Biotechnology, CHA University, Seongnam 13488, Korea \\ Correspondence to: Han Geuk Seo, email: hgseo@konkuk.ac.kr \\ Keywords: a disintegrin and metalloprotease domains with thrombospondin motifs 1, breast cancer cells, metastasis, peroxisome \\ proliferator-activated receptor $\delta$, thrombospondin- 1 \\ Received: July 04, $2017 \quad$ Accepted: September 21, 2017 Published: October 06, 2017 \\ Copyright: Ham et al. This is an open-access article distributed under the terms of the Creative Commons Attribution License 3.0 \\ (CC BY 3.0), which permits unrestricted use, distribution, and reproduction in any medium, provided the original author and source \\ are credited.
}

\section{ABSTRACT}

Migration and invasion of cancer cells into surrounding tissue is a key stage of cancer metastasis. Here, we show that peroxisome proliferator-activated receptor (PPAR) $\delta$ regulates migration and invasion of human breast cancer cells via thrombospondin-1 (TSP-1) and its degrading protease, a disintegrin and metalloprotease domains with thrombospondin motifs 1 (ADAMTS1). Activation of PPARס by GW501516, a specific ligand for PPARס, led to marked inhibition in the cell migration and TSP-1 expression of breast cancer. These effects were suppressed by small interfering RNA-mediated knock-down of ADAMTS1, indicating that ADAMTS1 is involved in PPARס-mediated inhibition of migration and TSP-1 expression in breast cancer cells. In addition, ligand-activated PPARठ upregulated expression of ADAMTS1 at the transcriptional level via binding of PPARठ to a direct repeat-1 site within the ADAMTS1 gene promoter. Furthermore, ligand-activated PPARठ suppressed invasion of breast cancer cells in an ADAMTS1-dependent manner. Taken together, these results demonstrate that PPARठ suppresses migration and invasion of breast cancer cells by downregulating TSP-1 in a process mediated by upregulation of ADAMTS1.

\section{INTRODUCTION}

Peroxisome proliferator-activated receptor $\delta$ (PPAR $\delta$ ), a ligand-inducible transcription factor belonging to the nuclear hormone receptor superfamily, mediates a number of processes, including energy metabolism, cellular growth and differentiation, and inflammatory responses [1]. PPAR $\delta$ promotes transcription of target genes by forming heterodimers with the retinoid $\mathrm{X}$ receptor via PPAR response elements (PPRE), which contain a direct repeat (DR1 or DR2) comprising six nucleotides (AGGTCA) separated by one or two nucleotides, present in the promoter region of target genes $[2,3]$. In addition to its normal homeostatic functions,
PPAR $\delta$ also plays roles in a number of disease processes, including type 2 diabetes, hyperlipidemia, atherosclerotic inflammation, and oncogenesis [1]. Although PPAR $\delta$ is expressed by several tumor-derived cell lineages and primary human tumors, including liver, prostate, colon, gastric, and breast cancers, its exact role in cancer development is unclear. Several studies demonstrate that activation of PPAR $\delta$ increases proliferation and tumorigenesis of melanoma, liver, intestinal adenoma, and prostate cancer cell lines [4-9]. Others, however, report that PPAR $\delta$ agonists inhibit proliferation of skin cancer, colon carcinoma, and lung adenocarcinoma [10-12]. Furthermore, recent studies show that ligandactivated PPAR $\delta$ inhibits proliferation of human breast and melanoma cancer cell lines $[13,14]$. 
Thrombospondin-1 (TSP-1) is a $450 \mathrm{kDa}$ oligomeric extracellular matrix glycoprotein that regulates several biological processes, including angiogenesis, cell adhesion, and tumor progression $[15,16]$. Initially, TSP1 was considered a potent inhibitor of tumor progression because increased TSP-1 expression suppresses growth or metastasis of human melanoma in vivo [17]. However, this effect appears to be cell type-specific, as demonstrated by a study showing that TSP-1 stimulates epithelial-tomesenchymal transition in human melanoma and breast carcinoma cells, leading to an aggressive phenotype [18]. Although the role of TSP-1 in melanoma is controversial, it has a carcinogenic effect that promotes metastasis and progression of breast cancer [16, 19, 20].

ADAMTS1 (a disintegrin and metalloprotease with thrombospondin motifs 1) is a zinc-binding metalloprotease broadly expressed by several adult tissues, and is implicated in tissue remodeling during cancer development and progression [21-23]. In fact, upregulation of ADAMTS1 occurs in highly metastatic pancreatic cancers [24]. By contrast, other studies provide conflicting evidence of its expression in human breast tumors [25, 26]. Accordingly, ADAMTS1 is considered to be both a pro- and an anti-tumorigenic factor, although the specific mechanisms underlying these are poorly understood.

Although the role of PPAR $\delta$ in the tumorigenicity of breast cancer is controversial, recent reports have shown the anti-proliferative activities of PPAR $\delta$ in breast cancer cells $[13,14]$. Thus, we hypothesized that ligandactivated PPAR $\delta$ plays a central role in the tumorigenicity of human breast cancers, by modulating the expression of TSP-1 through its degrading protease ADAMTS1. Here, we examined the association between TSP-1 and ADAMTS1 and the activity of ligand-activated PPAR $\delta$ in terms of migration and invasion of human breast cancer cells. We show that activation of PPAR $\delta$ by GW501516 inhibits migration and invasion of breast cancer cells, and that PPAR $\delta$ exerts its inhibitory effects by downregulating TSP-1 expression in a process mediated by transcriptional upregulation of ADAMTS1.

\section{RESULTS}

\section{Activation of PPAR $\delta$ suppresses migration of breast cancer cells}

First, we examined the effects of GW501516 on migration of human breast cancer cell lines MCF-7 and MDA-MB-231, which show low and high metastatic potential, respectively. When GW501516 was added to the culture medium of MCF-7 and MDA-MB-231 cells, it inhibited migration of the latter but not the former (Supplementary Figure 1). The inhibitory activity against MDA-MB-231 was concentration-dependent and was apparent at concentrations as low as $10 \mathrm{nM}$, reaching maximal inhibition at $100 \mathrm{nM}$. Consistent with the results in MDA-MB-231 cells, the migration of other high metastatic human breast cancer cell lines MDA-MB-435 and ZR-75-1 was dose-dependently inhibited in the presence of GW501516 (Figure 1).

\section{Activation of PPAR $\delta$ inhibits TSP-1 expression in breast cancer cells}

To examine the mechanisms underlying GW501516mediated inhibition of breast cancer cell migration, we targeted TSP-1, which induces tumor metastasis in human breast cancer [20]. Basal expression of TSP-1 in MDA-MB-231 cells was higher than that in MCF-7 cells (Supplementary Figure 2). Next, we exposed MDAMB-231 cells to GW501516 to further confirm whether GW501516-mediated suppression of MDA-MB-231 cell migration was dependent on TSP-1. We found that TSP1 expression decreased significantly and in a time- and dose-dependent manner. Maximum inhibitory activity was obtained after $48 \mathrm{~h}$ of exposure to $100 \mathrm{nM}$ GW501516 (Figure 2A). When cells were treated with $100 \mathrm{nM}$ GW501516, significant inhibition of TSP-1 protein levels was detected at $24 \mathrm{~h}$, reaching a maximum at $48 \mathrm{~h}$ (Figure 2B).

To further elucidate the role of PPAR $\delta$ in GW501516-mediated inhibition of TSP-1 expression, we transfected MDA-MB-231 cells with either small interfering (si)RNA specific for PPAR $\delta$ or control siRNA. $\operatorname{PPAR} \delta$ expression fell significantly in the presence of PPAR $\delta$ siRNA, but was unchanged in the presence of nonspecific control siRNA (Supplementary Figure 3). This siRNA-mediated downregulation of PPAR $\delta$ counteracted GW501516-mediated inhibition of expression of TSP1, whereas control siRNA had no effect on TSP-1 levels (Figure 2C). In addition, pretreating cells with GSK0660, an antagonist of PPAR $\delta$ [27], reversed the effect of GW501516 on TSP-1 expression (Figure 2D). Similar results are also observed in MDA-MB-435 and ZR-75-1 cells (Figure 2C and 2D). These data clearly indicate that PPAR $\delta$ is involved in GW501516-mediated inhibition of TSP-1 expression in breast cancer cells.

\section{Activation of PPAR $\delta$ inhibits migration and TSP-1 expression through ADAMTS1}

Because ADAMTS1, a zinc-binding metalloproteinase, recognizes TSP-1 as a substrate [21], we examined the role of ADAMTS1 in GW501516induced inhibition of TSP-1 in MDA-MB-231 cells. siRNA-mediated downregulation of ADAMTS1 counteracted the inhibitory effects of GW501516 on TSP-1 expression; these effects were not observed in the presence of control siRNA (Figure $3 \mathrm{~A}$ and $3 \mathrm{~B}$ ).

To confirm whether ADAMTS1-mediated inhibition of TSP-1 has a direct effect on GW501516-regulated 
cell migration, we performed a cell migration assay using the Transwell system and cells transfected with siRNA targeting ADAMTS1. Consistent with the effect of ADAMTS1 on TSP-1, ADAMTS1 siRNA (but not control siRNA) reversed the effects of GW501516 on cell migration (Figure 3C and 3D). These results suggest that the effects of GW501516 on the cell migration are regulated by ADAMTS1 via proteolytic degradation of TSP-1, a pro-metastatic factor, in breast cancer cells.

\section{Activation of PPAR $\delta$ induces ADAMTS1 expression}

To further examine the roles of ADAMTS1 in GW501516-mediated regulation of cell migration and TSP-1 expression, we investigated the effect of PPAR $\delta$ activation on expression of ADAMTS1 in MDA-MB-231 cells. When cells were treated with GW501516, the levels of ADAMTS1 mRNA and protein increased in a time-

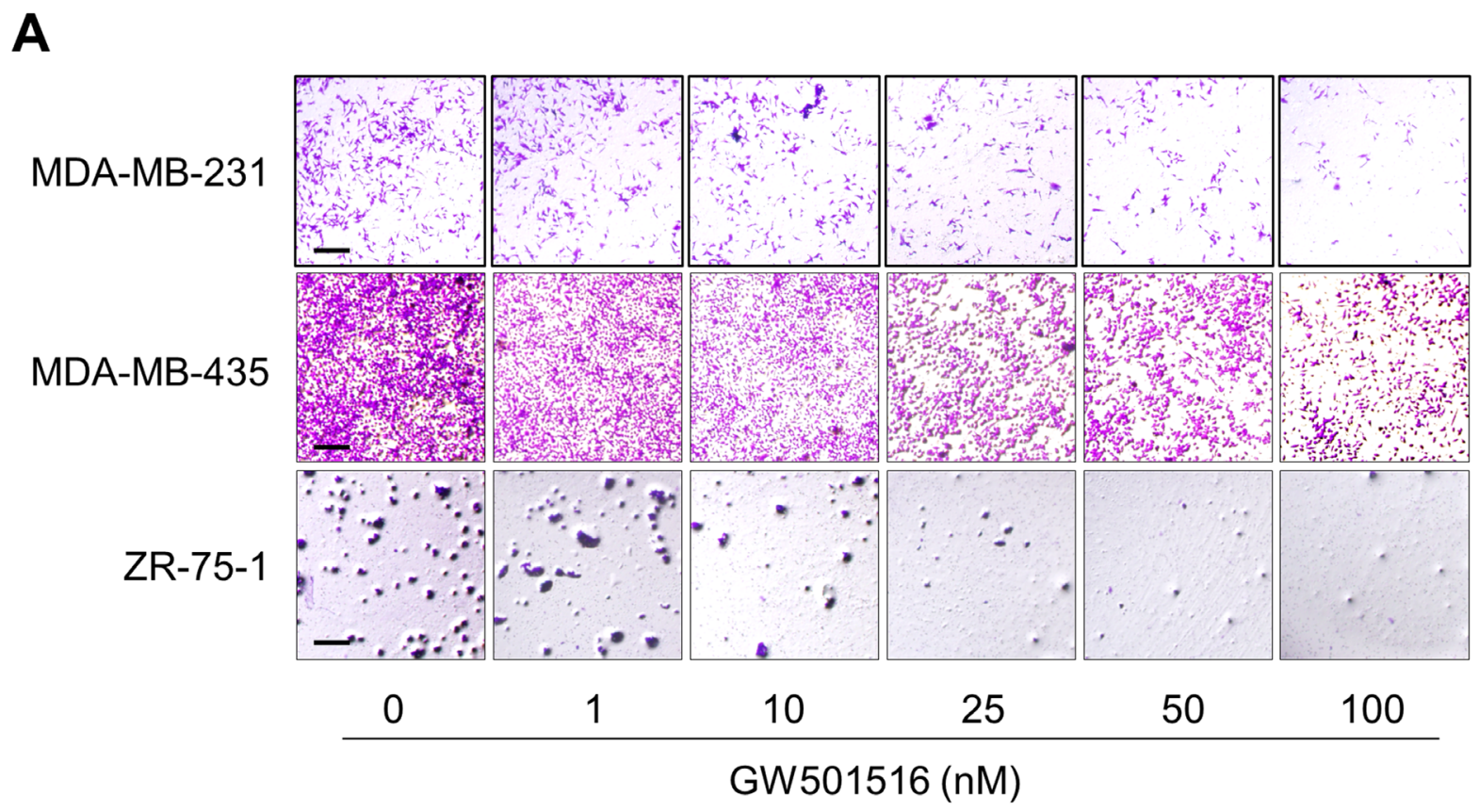

B
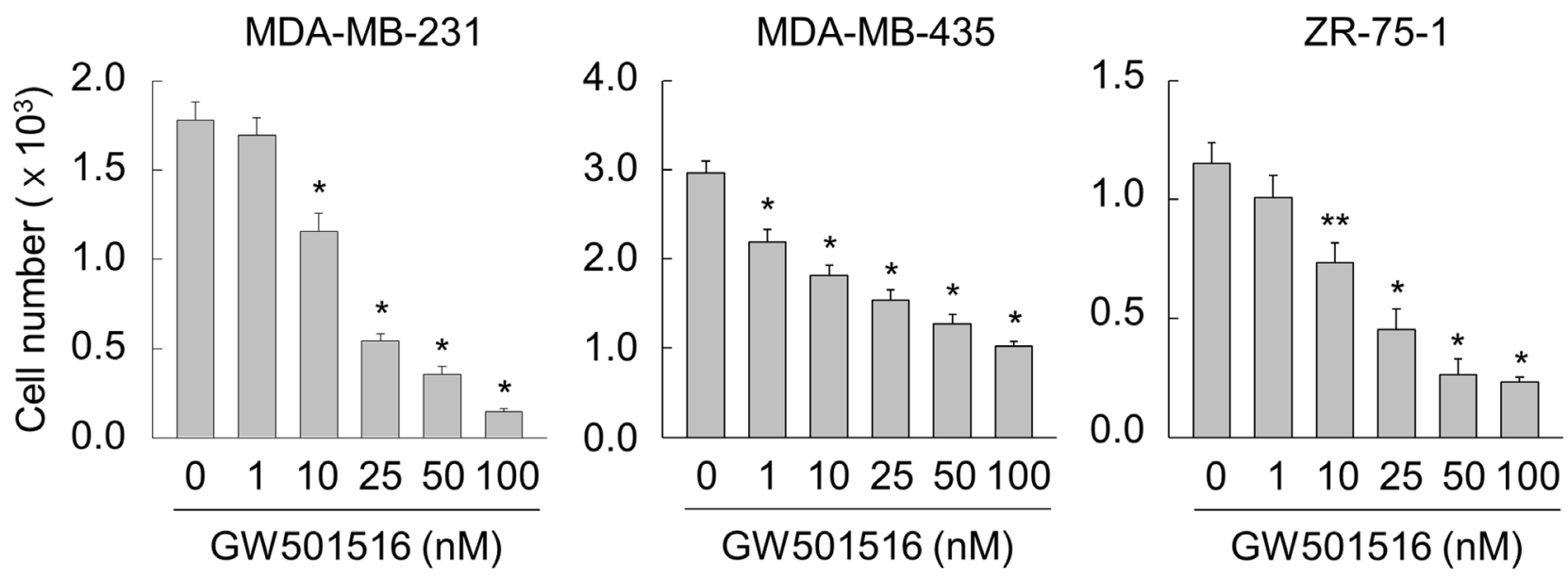

Figure 1: Activating PPAR $\delta$ inhibits migration of MDA-MB-231, MDA-MB-435, and ZR-75-1 cells. (A, B) Cells were incubated with various concentrations of GW501516. After $48 \mathrm{~h}$, cells were examined in migration assays (A) and migrating cells were quantitated (B). Representative images from four independent experiments are shown. Results are expressed as the mean $\pm \mathrm{SE}(\mathrm{n}=4)$. Bar, $100 \mu \mathrm{m} .{ }^{*} p<0.01,{ }^{* *} p<0.05$ compared with the untreated group. 
and dose-dependent manner. Maximum expression of ADAMTS1 mRNA and protein was observed after $24 \mathrm{~h}$

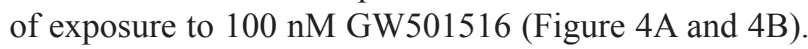
When cells were treated with 100 nM GW501516, significant elevation of ADAMTS1 mRNA and protein expression was detected at $6 \mathrm{~h}$, reaching a maximum at $24 \mathrm{~h}$ (Figure 4C and 4D).

To verify the role of PPAR $\delta$ in upregulation of ADAMTS1, we examined the effect of GW501516 in cells transfected with siRNA specific for PPAR $\delta$. Downregulation of PPAR $\delta$ led to marked suppression of GW501516-induced ADAMTS1 mRNA expression (Figure 4E). In addition, pretreatment with GSK0660 significantly inhibited GW501516-induced expression of ADAMTS1 mRNA (Figure 4F), confirming involvement of PPAR $\delta$ in GW501516-mediated upregulation of ADAMTS1 in breast cancer cells.

A
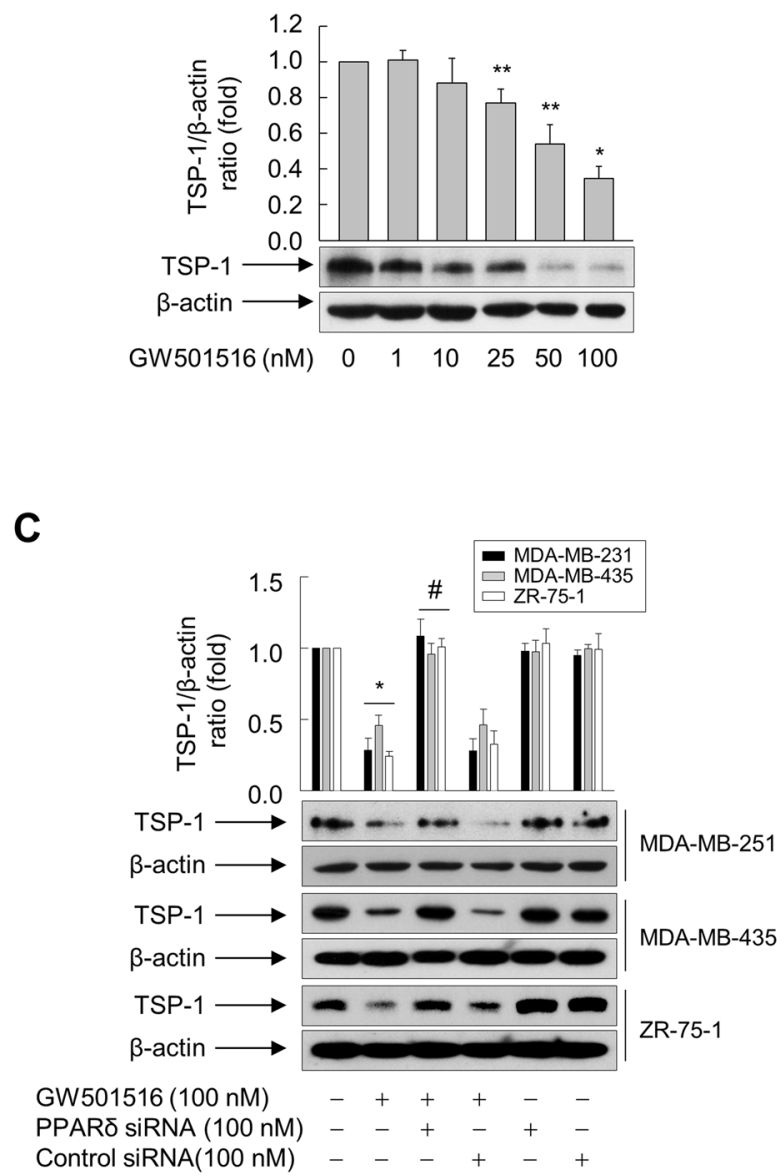

\section{Activation of PPAR $\delta$ increases the transcriptional activity of ADAMTS1}

To confirm whether GW501516-induced upregulation of ADAMTS1 occurs at the transcriptional level, we performed a reporter gene assay using a construct driven by the ADAMTS1 promoter. HEK293T cells were co-transfected with a luciferase expression vector carrying the $-1.6 \mathrm{~kb}$ upstream region of the human ADAMTS1 gene, along with an expression vector for $\beta$-galactosidase. Following incubation for $24 \mathrm{~h}$, cells were treated with vehicle or GW501516 for $48 \mathrm{~h}$. As shown in Figure 5A, GW501516 increased luciferase activity, supporting the previous finding that it induces expression of ADAMTS1 mRNA and protein. We then identified the promoter region responsible for GW501516-induced upregulation of ADAMTS1 using reporter assays and serially truncated

B
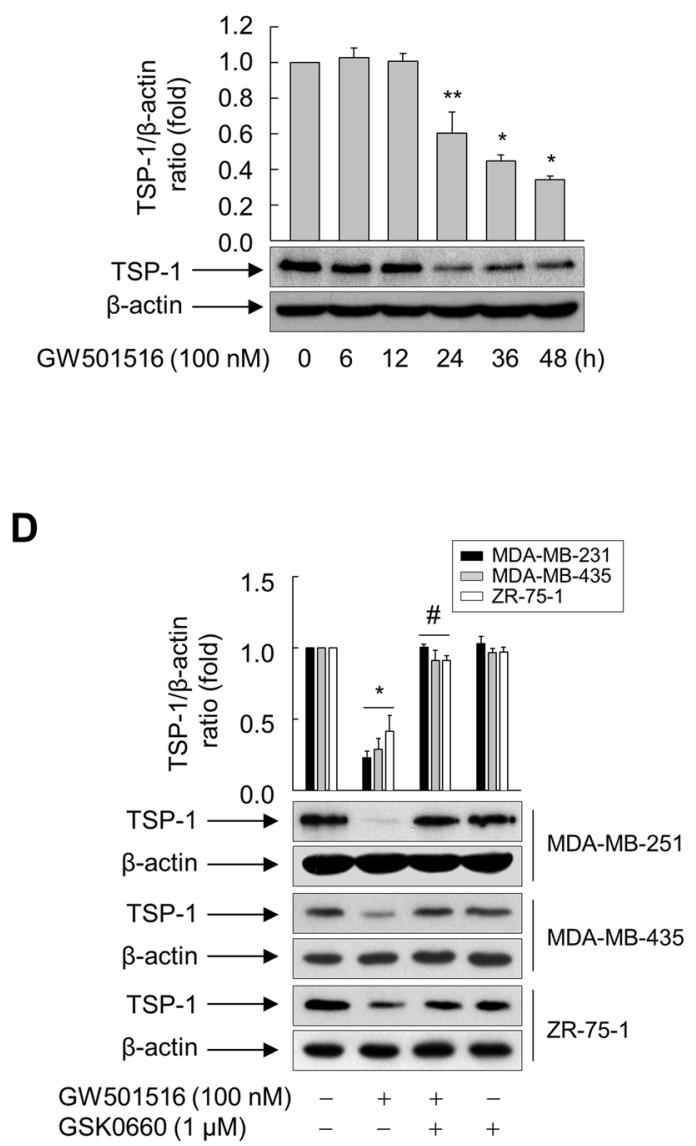

Figure 2: Activating PPAR inhibits TSP-1 expression in MDA-MB-231, MDA-MB-435, and ZR-75-1 cells. (A) MDAMB-231 cells were incubated with various concentrations of GW501516 for $48 \mathrm{~h}$. (B) MDA-MB-231 cells were treated with $100 \mathrm{nM}$ GW501516 for the indicated times. (C, D) Cells transfected with siRNA specific for PPAR $\delta$ or with control siRNA for $24 \mathrm{~h}(\mathrm{C})$ or pretreated with GSK0660 for $30 \mathrm{~min}$ (D) were exposed to GW501516 for $48 \mathrm{~h}$. The cells were then harvested, and an aliquot of total cell lysate was analyzed by Western blotting. Representative blots from three independent experiments are shown. Results are expressed as the mean $\pm \mathrm{SE}$ $(\mathrm{n}=3) .{ }^{*} p<0.01$ and ${ }^{* *} p<0.05$, compared with the untreated group; ${ }^{*} p<0.01$, compared with the GW501516-treated group. 
constructs driven by the ADAMTS1 promoter. The response to GW501516 was markedly reduced by deletion of sequences between nucleotides -451 and -342 (relative to the transcriptional start site at +1 ) of the ADAMTS1 promoter, indicating that the element responsible for the effects of GW501516 is located between -451 and -342 bases upstream of the ADAMTS1 gene.

To further confirm that this $-451 /-342$ region of the ADAMTS1 gene is responsible for the ability of $\operatorname{PPAR} \delta$ (activated by GW501516) to induce expression of ADAMTS1, we searched a database for PPRE homolog sequences in the -451 to -342 base region. A putative PPRE containing a direct repeat-1 (DR1) sequence was identified at positions -388 to -376 within the ADAMTS1 promoter (Figure 5B). To determine whether this putative PPRE is involved in PPAR $\delta$-mediated transcriptional activation, we introduced mutations into the DR1 site of the full-length ADAMTS1 promoter $(-1628 /+207)$. Activation of PPAR $\delta$ by GW501516 resulted in a 2.5-fold

A

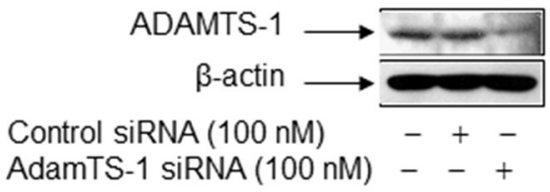

C

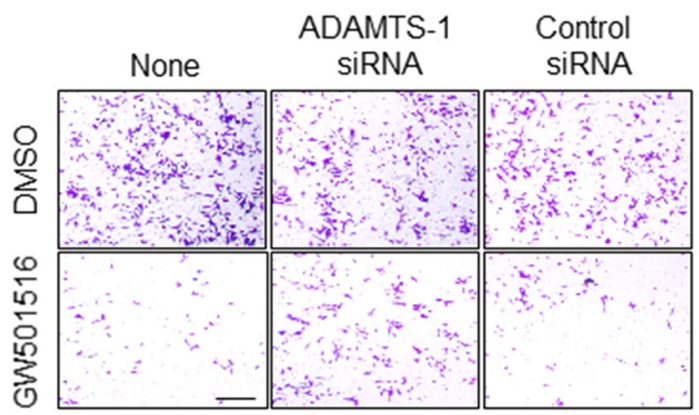

increase in transcriptional activity when compared with wild-type ADAMTS1-DR1 (ADAMTS1-DR $1_{w t}$ ). This increase in promoter activity was significantly attenuated in the presence of GSK0660. By contrast, the effect of GW501516 on the promoter activity of ADAMTS1 was almost completely abolished by mutation of the motif within ADAMTS1-DR1 (ADAMTS1-DR1 ${ }_{\mathrm{mt}}$; Figure 5C). These results clearly demonstrate that the ADAMTS1 promoter is transcriptionally regulated by PPAR $\delta$ through the DR1-type PPRE present upstream of the ADAMTS1 gene.

\section{PPAR $\delta$ is recruited to the ADAMTS1 promoter upon GW501516 treatment}

Next, we performed chromatin immunoprecipitation assays to further confirm that PPAR $\delta$ interacts directly with the ADAMTS1 promoter to trigger transcriptional upregulation. MDA-MB-231 cells were treated with
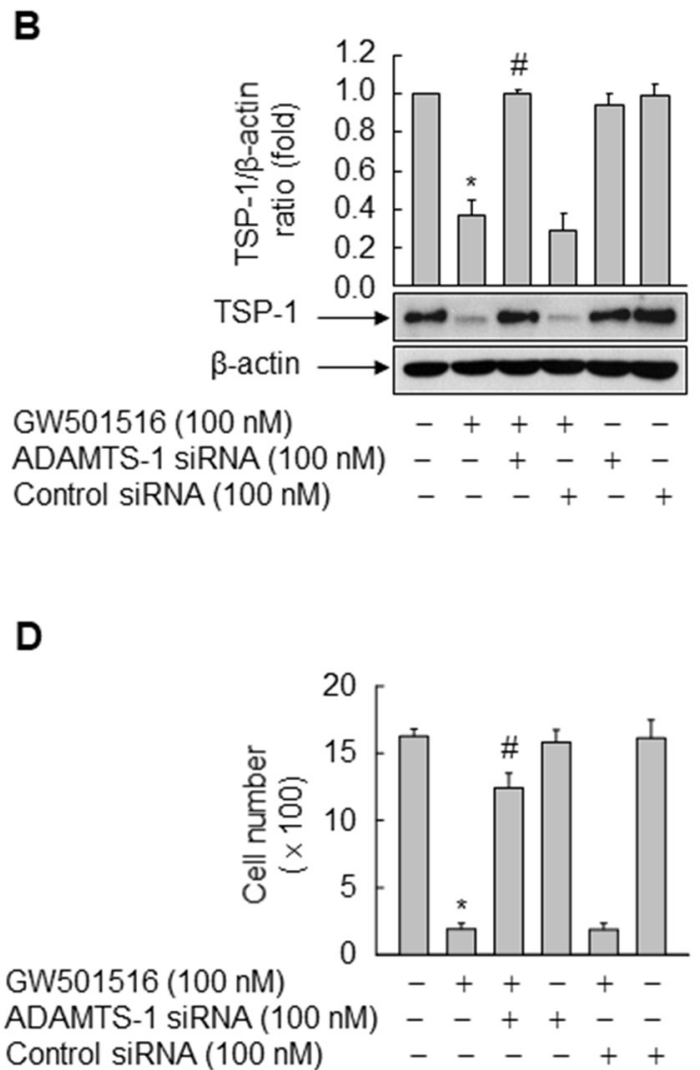

Figure 3: Activating PPAR $\delta$ inhibits cells migration and TSP-1 expression in MDA-MB-231 cells via ADAMTS1. (A) Cells were transfected with siRNA specific for ADAMTS1 or with control siRNA. Following incubation for $24 \mathrm{~h}$, cells were harvested and the effects of siRNA were evaluated by Western blot analysis. (B) Cells transfected with siRNA specific for ADAMTS1 or with control siRNA for $24 \mathrm{~h}$ were treated with or without $100 \mathrm{nM} \mathrm{GW501516.} \mathrm{After} 48 \mathrm{~h}$, cells were harvested and TSP-1 levels were analyzed by Western blotting. (C, D) Cells transfected with siRNA specific for ADAMTS1 or with control siRNA for $24 \mathrm{~h}$ were treated with 100 nM GW501516 or vehicle (DMSO). After $48 \mathrm{~h}$, cells were examined in migration assays (C) and migrating cells were counted (D). Representative blots or images from three or four independent experiments are shown. Results are expressed as the mean $\pm \mathrm{SE}(\mathrm{n}=3$ or 4$)$. Bar, $100 \mu \mathrm{m} .{ }^{*} p<0.01$, compared with the untreated group; ${ }^{*} p<0.01$, compared with the GW501516-treated group. 
GW501516 for $0,6,12$, and $24 \mathrm{~h}$, and chromatin fragments were subjected to immunoprecipitation with an anti-PPAR $\delta$ antibody. Genomic DNA from the immunoprecipitates was amplified by PCR using primers specific for promoter sequences containing the putative ADAMTS1-DR1 site (Figure 6A). The association between PPAR $\delta$ and the PCR-amplified region was detected in fragments amplified by primers targeting Oligo $\# 1$, whereas no reactivity was observed with fragments amplified with upstream primers targeting Oligo \#2 (Figure 6B). These results are in line with the findings from the reporter gene assay, suggesting that GW501516activated PPAR $\delta$ regulates transcriptional activity of the ADAMTS1 gene.

\section{Activation of PPAR $\delta$ suppresses invasion of breast cancer cells via ADAMTS1}

TSP-1 is reported to induce an invasive phenotype in various cancer cells [28-30], we asked whether GW501516-activated PPAR $\delta$ induces phenotypic changes, such as invasion, via ADAMTS-1-mediated regulation of TSP-1 in breast cancer cells. Cells not treated with GW501516 showed a highly aggressive and invasive phenotype in a Transwell assay. This was markedly attenuated by GW501516; however, transfection of siRNA specific for ADAMTS1 or PPAR $\delta$ (but not control siRNA) almost completely abolished the inhibitory effects of GW501516 (Figure 7A and 7B). These results clearly

B

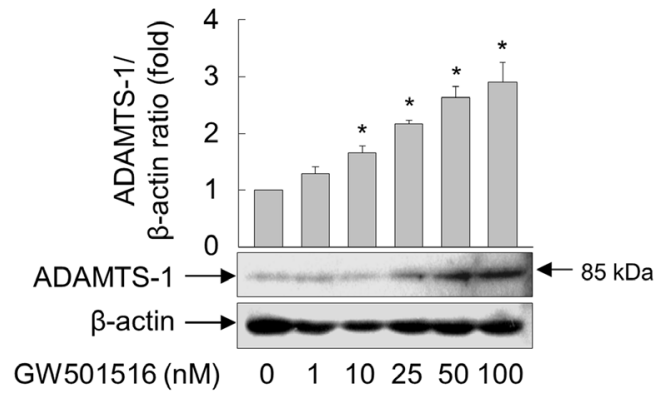

D

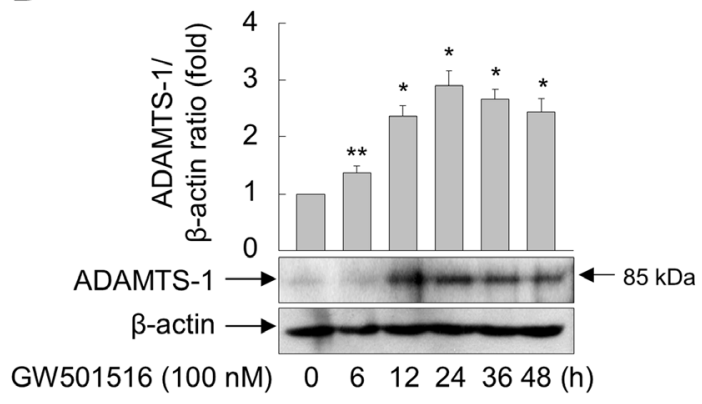

$\mathbf{F}$

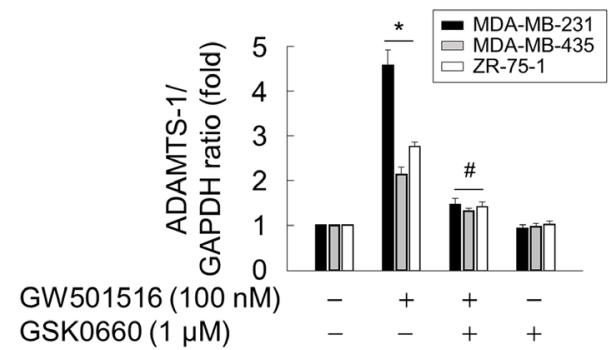

Figure 4: Activating PPARס induces ADAMTS1 expression in MDA-MB-231, MDA-MB-435, and ZR-75-1 cells. (A, B) MDA-MB-231 cells were incubated with various concentrations of GW501516 for $48 \mathrm{~h}$. (C, D) MDA-MB-231 cells were incubated with or without $100 \mathrm{nM} \mathrm{GW501516}$ for the indicated times. (E, F) Cells transfected with siRNA specific for PPAR $\delta$ or with control siRNA for $24 \mathrm{~h}(\mathrm{E})$ or pretreated with GSK0660 for $30 \mathrm{~min}(\mathrm{~F})$ were exposed to GW501516 for $24 \mathrm{~h}$. The cells were then harvested, and levels of ADAMTS1 mRNA (A, C, E, F) and protein (B, D) were analyzed by real-time PCR and immunoblotting, respectively. Representative blots from three independent experiments are shown. Results are expressed as the mean $\pm \mathrm{SE}(\mathrm{n}=3) .{ }^{*} p<0.01$ and ${ }^{* *} p<0.05$, compared with the untreated group; ${ }^{*} p<0.01$ and ${ }^{\# \#} p<0.05$, compared with the GW501516-treated group. 
indicate that GW501516-activated PPAR $\delta$ is involved in suppression of cell invasion, and that ADAMTS1 mediates the actions of PPAR $\delta$ in human breast cancer cells.

\section{DISCUSSION}

Here, we show that the GW501516-mediated activation of PPAR $\delta$ suppresses migration and invasion of human breast cancers MDA-MB-231, MDA-MB-435, and ZR-75-1 cells. This effect is mediated by ADAMTS1, a metalloproteinase that utilizes the TSP-1 protein as a substrate [21]. Transfection experiments demonstrated that ADAMTS1 expression was regulated by PPAR $\delta$ at the transcriptional level. Mutation of the DR1 site located within the ADAMTS1 promoter region abolished GW501516-induced ADAMTS1 transcription, indicating that this region is a novel PPRE. Furthermore, GW501516activated PPAR $\delta$ suppressed invasion of human breast cancer cells via a mechanism mediated by ADAMTS1.

Although the role of PPAR $\delta$ in tumorigenesis is highly controversial, the present data demonstrated that ligand-activated PPAR $\delta$ suppresses migration and invasion of human breast cancer cells. A recent study also showed that activation of PPAR $\delta$ by specific ligands reduced the tumorigenicity of xenografts by manipulating expression of PPAR $\delta$ [13]. In particular, activation of $\operatorname{PPAR} \delta$ negatively regulates invasion and metastasis of human pancreatic cancer cells by downregulating genes associated with these biological processes [31], thereby supporting the findings presented herein. In contrast to the present study, other studies show that administration of a PPAR $\delta$ agonist, GW501516, promotes mammary

\section{A}

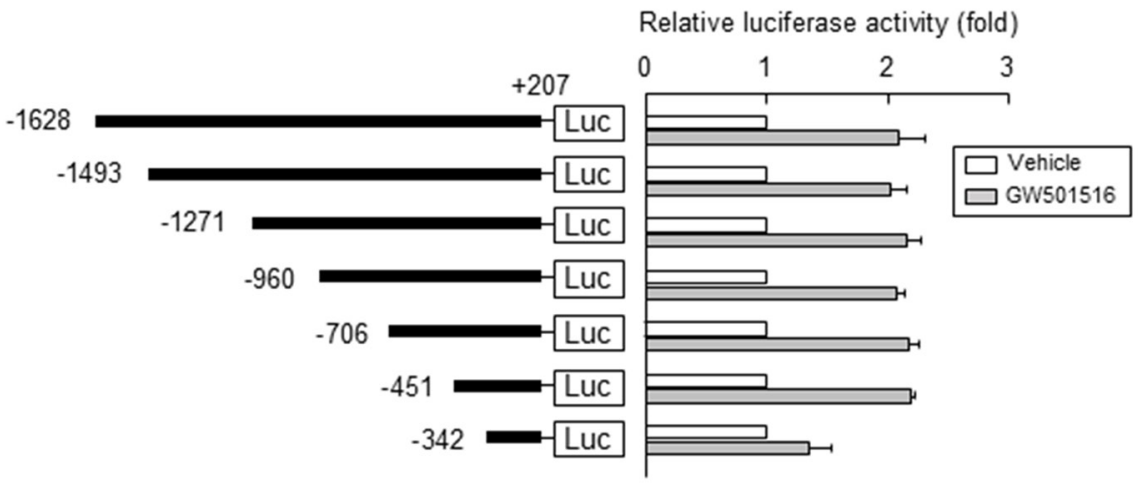

B

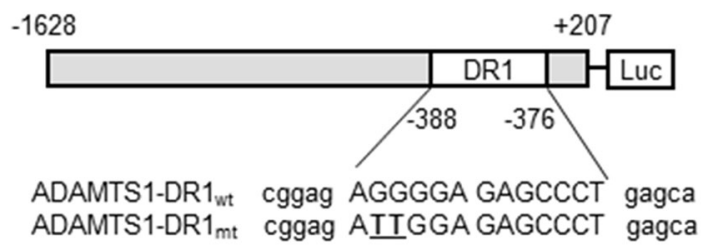

C

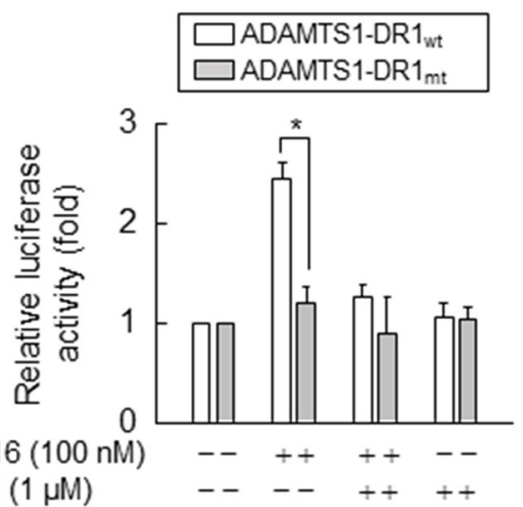

Figure 5: Activating PPARס increases ADAMTS1 promoter activity via the PPRE site. (A) HEK293T cells were transfected with ADAMTS1 gene promoter constructs $(1 \mu \mathrm{g})$ and the SV40 $\beta$-Galactosidase expression vector (pSV $\beta$-Gal, $0.5 \mu \mathrm{g})$. Transfectants were grown for $24 \mathrm{~h}$ and then treated with $100 \mathrm{nM} \mathrm{GW} 501516$ or vehicle for $48 \mathrm{~h}$. (B) Schematic representation of the ADAMTS1 promoter. The potential DR1-type PPRE was mutated by site-directed mutagenesis (mutated sites underlined in bold). (C) HEK293T cells pretreated for 30 min with GSK0660 were transfected with luciferase reporter plasmids $(1 \mu \mathrm{g})$ driven by the ADAMTS1 promoter and with a pSV $\beta$-Gal plasmid $(0.5 \mu \mathrm{g})$. Transfectants were grown for $24 \mathrm{~h}$ and then treated with GW501516 for $48 \mathrm{~h}$. Luciferase activity was determined and normalized to $\beta$-galactosidase activity. Data are expressed as the mean $\pm \mathrm{SE}$ of four independent transfections $(\mathrm{n}=4)$. ${ }^{*} p<0.01$, compared with the untreated group; ${ }^{*} p<0.01$ compared with the GW501516-treated group. 
$-1628$

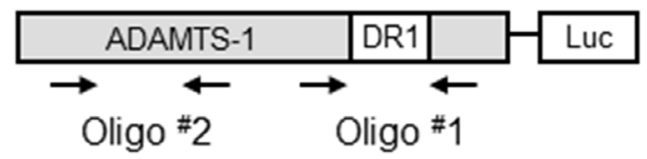

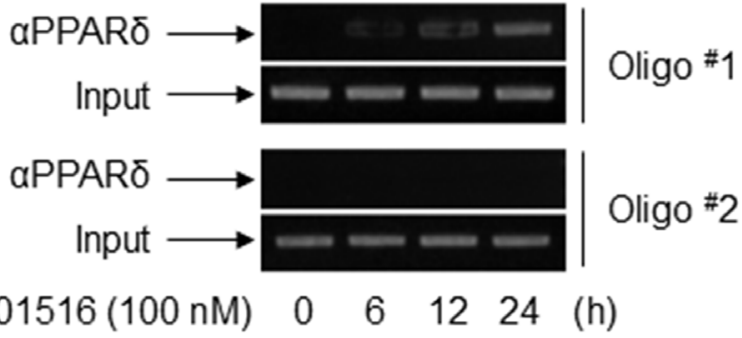

Figure 6: PPAR $\delta$ associates physically with the PPRE within the ADAMTS1 promoter in MDA-MB-231 cells. (A) Schematic location of the primer sets used for PCR amplification. Oligo \#1 and Oligo \#2 depict regions corresponding to the DR1type PPRE site and an upstream region, respectively. (B) Cells were incubated with GW501516 for the indicated times. Chromatin was immunoprecipitated with an anti-PPAR $\delta$ antibody, and genomic DNA was amplified by PCR using either the Oligo \#1 or Oligo \#2 primer set. Control amplifications were performed with input chromatin obtained before immunoprecipitation. Results are representative of three independent experiments.

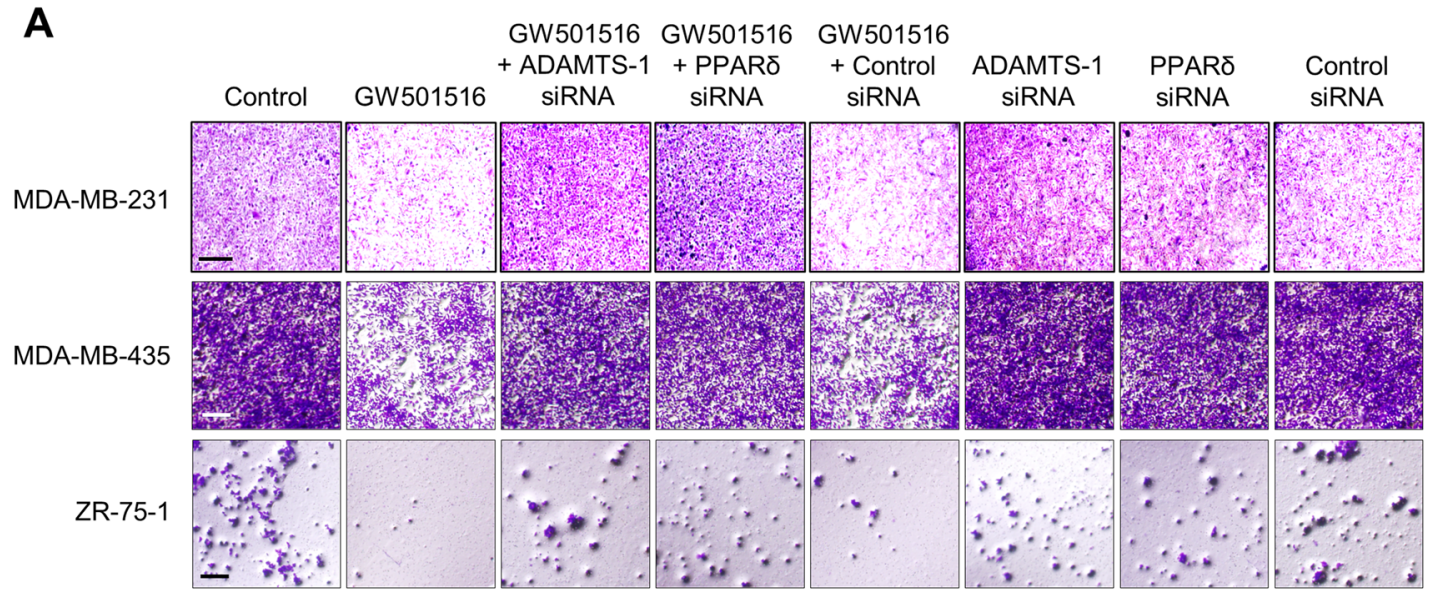

B

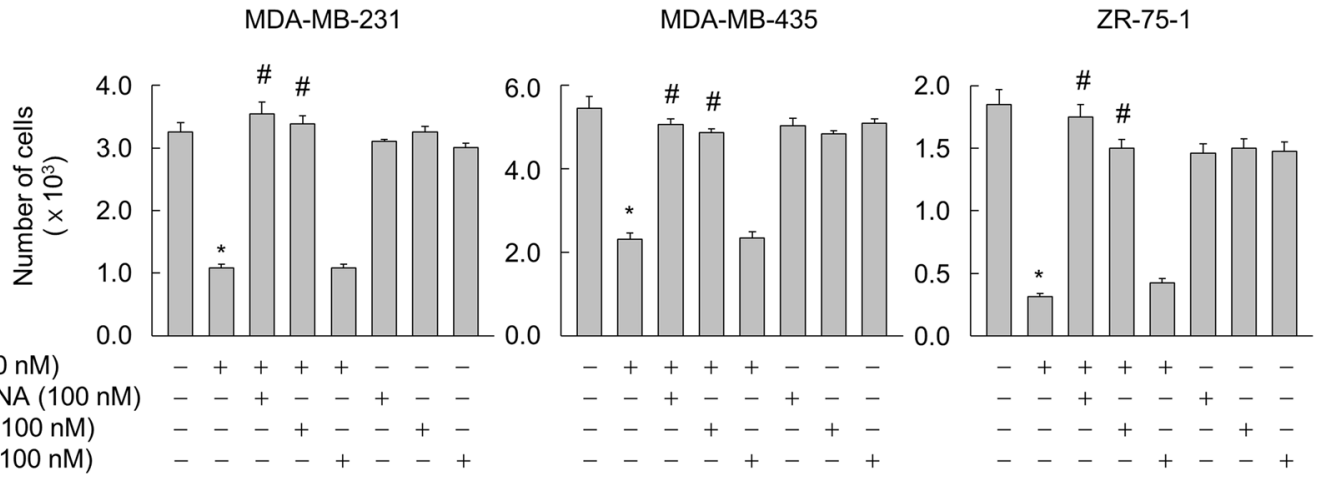

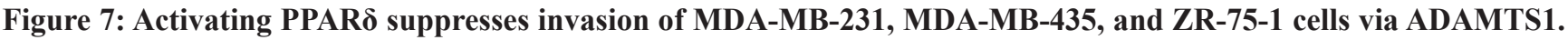
(A, B) Cells transfected with siRNA specific for ADAMTS1 or PPAR $\delta$, or with control siRNA, for $24 \mathrm{~h}$ were treated with $100 \mathrm{nM}$ GW501516 or vehicle. Following incubation for $72 \mathrm{~h}$, cells were subjected to invasion assays (A) and cells migrating to the lower chamber were counted (B). Representative images from four independent experiments are shown. Results are expressed as the mean \pm SE $(n=4)$. Bar, $100 \mu \mathrm{m} .{ }^{*} p<0.01$, compared with the untreated group; ${ }^{*} p<0.01$, compared with the GW501516-treated group. 
tumorigenesis via changes in the inflammatory and metabolic phenotype linked to mammalian target of rapamycin (mTOR) activation or 3-phosphoinositidedependent kinase-1 (PDK1) and Akt signaling [8, 9, 32]. Thus, the exact role of PPAR $\delta$ agonists in cancer development appears to depend on the properties and doses of the ligands tested [14]. In fact, different studies report that PPAR $\delta$ can promote or inhibit tumorigenesis in MCF-7 human breast cancer cells [7, 14]. However, the present data clearly demonstrate that GW501516-activated PPAR $\delta$ suppresses migration and invasion of human breast cancers MDA-MB-231, MDA-MB-435, and ZR-75-1 cells.

GW501516-activated PPAR $\delta$ significantly downregulates TSP-1 expression by MDA-MB-231, MDA-MB-435, and ZR-75-1 human breast cancer cells. TSP-1 promotes an aggressive phenotype in human melanoma via epithelial-to-mesenchymal transition [18], whereas it suppresses metastasis in human melanoma xenografts [17]. Although the role of TSP-1 in migration and invasion of cancer cells is unclear, other studies consistently demonstrate that TSP-1 promotes metastasis and progression of breast cancer [16, 19, 20, 33]. In particular, TSP-1 upregulates MMP-9 expression by gastric tumors, resulting in acquisition of an aggressive phenotype [34]. Consistent with our previous study demonstrating involvement of $\operatorname{PPAR} \delta$ in negative regulation of melanoma cell migration and invasion [4], we found here that PPAR $\delta$-mediated downregulation of TSP-1 is likely responsible for inhibition of aggressive breast cancer. In line with this, another study shows that ligand-activated PPAR $\gamma$, another sub-member of the PPAR family, suppresses hypoxia-induced expression of TSP1 in human pulmonary artery smooth muscle cells [35]. Accordingly, it is possible that PPAR $\delta$ may also inhibit TSP-1 in other types of cancer, particularly melanoma; further studies are needed to clarify the exact role of PPAR $\delta$ in expression of TSP-1.

PPAR $\delta$-induced upregulation of ADAMTS1 is a key event during PPAR $\delta$-dependent suppression in the migration and invasion of human breast cancers MDAMB-231, MDA-MB-435, and ZR-75-1 cells. The role of ADAMTS1 in tumorigenesis is highly ambiguous due to opposing results observed by different studies [23, 26, 36, 37]. Lu et al. report that ADAMTS1 is overexpressed in breast tumors, and that this overexpression is associated with an increased risk of bone metastasis [36]. In addition, breast cancer cells induce stromal fibroblasts to secrete ADAMTS1, thereby facilitating cancer cell invasion [37]. However, ADAMTS1 suppresses migration and invasion of liver and human breast tumors [26, 38]. In particular, ADAMTS1 expression correlates positively with migration and invasion of human breast cancer MDA-MB-231 cells [26]. In line with these reports, the present study demonstrates that activation of $\operatorname{PPAR} \delta$ by a specific agonist induces expression of ADAMTS1 mRNA and protein, thereby inhibiting migration and invasion of human breast cancer cells as reported previously [26]. ADAMTS1 was originally shown to be induced during the early phase of acute myocardial infarction [39]. In hepatoma cells, expression of ADAMTS1 is regulated differentially by SP1 (specificity protein 1) and USF1 (upstream stimulatory factor 1) under normoxic and hypoxic conditions [40]. Here, we identified a novel DR1-type PPRE as a cis-element within the promoter region of the ADAMTS1 gene and demonstrated that it is responsible for PPAR $\delta$-mediated upregulation.

The present findings show that activation of PPAR $\delta$ regulates migration and invasion of human breast cancers MDA-MB-231, MDA-MB-435, and ZR-75-1 cells by upregulating ADAMTS1 expression, thereby modulating the level of TSP-1. The effect of a PPAR $\delta$ ligand (GW501516) on ADAMTS1 expression mediates the function (e.g., anti-tumor activity) of PPAR $\delta$. Accordingly, the current findings support the assumption that PPAR $\delta$ is an important target for therapeutic strategies for neoplastic disorders.

\section{MATERIALS AND METHODS}

\section{Materials}

GW501516 and GSK0660 were purchased from Enzo Life Sciences (Farmingdale, NY, USA) and Tocris Bioscience (Bristol, UK), respectively. A monoclonal antibody specific for TSP-1 and polyclonal antibodies specific for PPAR $\delta$ and ADAMTS1 were purchased from Santa Cruz Biotechnology (Dallas, TX, USA). Polyclonal rabbit anti- $\beta$-actin antibody, mitomycin $C$, and crystal violet were obtained from Sigma-Aldrich (St. Louis, MO, USA). Small interfering (si)RNA specific for human ADAMTS1 was purchased from Bioneer (Daejeon, Korea). Control siRNA and human PPAR siRNA were obtained from Ambion (Austin, TX, USA).

\section{Cell culture}

Human breast cancer cell lines MCF-7, MDAMB-231, and ZR-75-1 cells were obtained from the Korean Cell Line Bank and maintained in Roswell Park Memorial Institute medium (RPMI-1640) containing antibiotics and $10 \%$ fetal bovine serum. Human breast cancer cell line MDA-MB-435 cells (a kind gift from Dr. Hyejung Mok; Department of Bioscience and Biotechnology, Konkuk University, Seoul, Korea) were cultured in Dulbecco's modified Eagle's medium containing antibiotics and 10\% fetal bovine serum. Human embryonic kidneyHEK293T cells were also acquired from the Korean Cell Line Bank and maintained in Dulbecco's modified Eagle's medium containing antibiotics and $10 \%$ fetal bovine serum. All cells were incubated in each 
medium at $37^{\circ} \mathrm{C}$ under a humidified atmosphere of $95 \%$ air and $5 \% \mathrm{CO}_{2}$.

\section{Gene silencing with siRNA}

Breast cancer cells were seeded into $60 \mathrm{~mm}$ culture dishes $18-24 \mathrm{~h}$ prior to transfection. Cells in serum-free medium were transfected with siRNA targeting human PPAR $\delta$, human ADAMTS1, or nonspecific sequences using Welfect-Q (WelGENE, Daegu, Korea). After incubation for $6 \mathrm{~h}$, the transfection medium was replaced with fresh medium containing $10 \%$ FBS and antibiotics. After incubation for $48 \mathrm{~h}$, cells were treated with the indicated reagents for the indicated times and the effects of gene silencing were assessed.

\section{Real-time PCR}

Expression of mRNA was determined by real-time PCR as described previously [4]. Briefly, total RNA was extracted from cells using TRIzol reagent (Invitrogen, Carlsbad, CA, USA) and reverse transcribed into cDNA using the TOPscript RT DryMIX kit (Enzynomics, Seoul, Korea). Equal amounts of cDNA in a $10 \mu \mathrm{l}$ reaction volume containing $2 \times$ Real-Time PCR Smart mix (Solgent, Daejeon, Korea) and primers $(10 \mathrm{pM})$ were amplified by real-time PCR using a MJ Research PTC200 Thermal Cycler (Bio-Rad, Hercules, CA, USA). After an initial denaturation step for $5 \mathrm{~min}$ at $95^{\circ} \mathrm{C}$, the reaction conditions were as follows: 40 cycles of $10 \mathrm{~s}$ at $95^{\circ} \mathrm{C}$, $10 \mathrm{~s}$ at $56^{\circ} \mathrm{C}$, and $10 \mathrm{~s}$ at $72^{\circ} \mathrm{C}$. mRNA expression was normalized against that of GAPDH mRNA in the same sample. The following primers were used: ADAMTS1 forward, 5'-TGT GGT GTT TGC GGG GGA AAT G-3' and reverse, 5'-TCG ATG TTG GTG GCT CCA GTT-3'; and $G A P D H$ forward, $5^{\prime}$-CAT GGC CTT CCG TGT TCC TA-3', and reverse, 5'-CCT GCT TCA CCA CCT TCT TGA T-3'.

\section{Western blot analysis}

Protein expression was assessed by Western blot analysis as described previously [4]. Briefly, cells treated with the indicated reagents were washed in ice-cold phosphate-buffered saline (PBS) and lysed in PRO-PREP Protein Extraction Solution (iNtRON Biotechnology, Seoul, Korea). Aliquots of cell lysates were subjected to SDS-polyacrylamide gel electrophoresis and transferred onto a Hybond- $\mathrm{P}^{+}$polyvinylidene difluoride membrane (GE Healthcare, Little Chalfont, UK). Membranes were blocked overnight at $4{ }^{\circ} \mathrm{C}$ with $5 \%$ nonfat milk in Trisbuffered saline (TBS) containing $0.1 \%$ Tween-20. After a brief wash with TBS, the membranes were incubated overnight at $4{ }^{\circ} \mathrm{C}$ with the indicated primary antibodies in TBS containing $0.05 \%$ Tween- 20 , followed by peroxidaseconjugated mouse, goat, or rabbit antibodies for $1 \mathrm{~h}$ at room temperature. After extensive washing in TBS containing $0.1 \%$ Tween-20, immunoreactive bands were detected using West-ZOL Plus (iNtRON Biotechnology).

\section{Plasmid construction and site-directed mutagenesis}

Luciferase reporter constructs (pGL3-ADAMTS1) containing the promoter region of the human ADAMTS1 gene (nucleotides $-1628 /+207,-1493 /+207,-1271 /+207$, $-960 /+207,-706 /+207,-451 /+207$, or $-342 /+207)$ were generously provided by Dr. Satoshi Hirohata (Okayama University, Okayama, Japan). Nucleotide substitutions were introduced into the DR1 site of the ADAMTS1 promoter using the QuikChange site-directed mutagenesis kit (Stratagene, La Jolla, CA, USA). PCR amplification of the wild-type human pGL3-ADAMTS1 luciferase reporter plasmid (nucleotides -1628/+207) was performed using site-directed mutation primers (ADAMTS1-DR ${ }_{\mathrm{m}}: 5^{\prime}-$ CGC TAC CGG ACG GAG ATT GGA GAG CCC TGA GCA GAG-3' and 5'-CTC TGC TCA GGG CTC TCC AAT CTC CGT CCGGTA GCG-3'). The substituted bases are indicated in bold. PCR amplification was performed using $5 \mathrm{ng}$ of template DNA; reaction conditions comprised 12 cycles of $95^{\circ} \mathrm{C}$ for $1 \mathrm{~min}, 55^{\circ} \mathrm{C}$ for $1 \mathrm{~min}$, and $68^{\circ} \mathrm{C}$ for 7 min. PCR products were digested with $D p n \mathrm{I}$ for $1 \mathrm{~h}$ at $37^{\circ} \mathrm{C}$ prior to transformation into competent Escherichia coli DH5 $\alpha$ cells. The integrity of the constructs was verified by sequencing.

\section{Reporter gene assay}

Cells were seeded into 6-well tissue culture plates 18-24 h prior to transfection and then co-transfected with the indicated luciferase reporter plasmids and $\mathrm{pSV}$ $\beta$-Gal (SV40 $\beta$-galactosidase expression vector, Promega, Madison, WI, USA) using the SuperFect reagent (Qiagen, Valencia, CA, USA). Following incubation for $24 \mathrm{~h}$, cells were treated with vehicle (DMSO) or GW501516 for 48 h. Cells were then lysed in luciferase reporter lysis buffer (Promega), and luciferase activity was determined by normalizing transfection efficiency using $\beta$-galactosidase activity, as described previously [41].

\section{Chromatin immunoprecipitation assay}

Binding of nuclear proteins to DNA was determined as described previously [41]. Briefly, nuclear proteins were cross-linked to genomic DNA by incubating them with $1 \%$ formaldehyde for $10 \mathrm{~min}$ at room temperature. Cells were collected (by scraping) in ice-cold PBS containing protease inhibitors and then centrifuged to obtain pellets that were resuspended in lysis buffer (1\% SDS, $10 \mathrm{mM}$ EDTA, and $50 \mathrm{mM}$ Tris-Cl, $\mathrm{pH}$ 8.1) containing protease inhibitors. These were incubated on ice for $30 \mathrm{~min}$. After sonication and centrifugation, the supernatants were rotated with 
protein G-Sepharose ${ }^{\mathrm{TM}} 4$ Fast Flow beads for $1 \mathrm{~h}$ at $4^{\circ} \mathrm{C}$. Following immunoprecipitation with an anti-PPAR $\delta$ antibody for $72 \mathrm{~h}$ at $4^{\circ} \mathrm{C}$, protein G-Sepharose beads were added and rotated for $2 \mathrm{~h}$ at $4^{\circ} \mathrm{C}$. The resulting immune complexes were precipitated by centrifugation and then sequentially washed in low-salt wash buffer (0.1\% SDS, 1\% TritonX-100, 2 mM EDTA, 20 mM Tris$\mathrm{Cl}$, and $150 \mathrm{mM} \mathrm{NaCl}, \mathrm{pH} 8.1$ ), high-salt wash buffer (0.1\% SDS, 1\% TritonX-100, 2 mM EDTA, $20 \mathrm{mM}$ Tris-Cl, and $500 \mathrm{mM} \mathrm{NaCl}, \mathrm{pH} 8.1$ ), LiCl wash buffer (0.25 M LiCl, 1\% IGEPAL-CA630, 1\% deoxycholic acid, $1 \mathrm{mM}$ EDTA, and $10 \mathrm{mM}$ Tris-Cl, $\mathrm{pH} \mathrm{8.1),} \mathrm{and}$ TE buffer (10 mM Tris-Cl, 1 mM EDTA, pH 8.0). After centrifugation, the immune complexes were resuspended in $200 \mu \mathrm{l}$ of elution buffer ( $1 \%$ SDS and $\left.0.1 \mathrm{M} \mathrm{NaHCO}_{3}\right)$ and incubated for $30 \mathrm{~min}$ at room temperature. After another centrifugation, the supernatant was collected and cross-linking was reversed by adding $5 \mathrm{M} \mathrm{NaCl}$ to a final concentration of $125 \mathrm{mM}$ for $5 \mathrm{~h}$ at $65^{\circ} \mathrm{C}$. The remaining proteins were digested with proteinase $\mathrm{K}$, and genomic DNA fragments were recovered by phenol-chloroform extraction, followed by ethanol precipitation and resuspension in sterile $\mathrm{H}_{2} \mathrm{O}$. Human genomic sequences containing the putative PPAR $\delta$ binding site (DR1, Oligo \#1, -459/-157) and a region upstream of the PPRE (Oligo \#2, -1237/-932) in the human ADAMTS1 promoter were amplified using the following primers: Oligo \#1, 5'-TTC TTG CAC TCG CTG GAA AG-3' and 5'-CTC CCG GAG TCA CTA AAA GG-3'; and Oligo \#2, 5'-CCA GAT CAC CCA TTC CAG AA-3' and 5'-TGA GCT AGG GCT ACA CTT TC-3'.

\section{Cell invasion and migration assay}

Transwells were fitted with polycarbonate membranes ( $8 \mu \mathrm{m}$ pores) (BD Biosciences, Franklin Lakes, NJ, USA), which were coated with collagen type I ( $1 \mathrm{mg} / \mathrm{ml}$; BD Biosciences $)$ for $1 \mathrm{~h}$ at $37^{\circ} \mathrm{C}$. After washing once with culture medium, cells were seeded into the upper compartment of the Transwell insert (8 $\times 10^{4}$ cells/well) in culture medium containing $8 \mu \mathrm{g} / \mathrm{ml}$ mitomycin C (Sigma-Aldrich) to prevent proliferation. The cells were incubated for $2 \mathrm{~h}$ and washed with PBS. Medium containing vehicle (DMSO) or GW501516 was then added to the lower well as a chemo-attractant. After incubation for the indicated times, cells were fixed with $4 \%$ paraformaldehyde for $10 \mathrm{~min}$ and permeabilized with $\mathrm{MeOH}$ for $20 \mathrm{~min}$ at room temperature. After staining with $0.05 \%$ crystal violet solution for $15 \mathrm{~min}$ at room temperature, the upper insert of the Transwell was removed. Invading cells in the lower chamber of the Transwell insert were counted under a microscope. For the cell migration assay, cells were treated using the same procedure, except that the Transwell membrane was not coated with type I collagen.

\section{Statistical analysis}

Data are expressed as the mean \pm SE. Statistical significance was determined using Student's $t$-test or ANOVA with post hoc (Bonferroni) correction for multiple comparisons. A value of $p<0.05$ was considered statistically significant.

\section{Abbreviations}

ADAMTS1, a disintegrin and metalloprotease with thrombospondin 1; DR1, direct repeat-1; mTOR, mammalian target of rapamycin; PDK1, 3-phosphoinositide-dependent kinase-1; PPAR $\delta$, peroxisome proliferator-activated receptor $\delta$; PPRE, PPAR response elements; SP1, specificity protein 1; TSP-1, thrombospondin-1; USF1, upstream stimulatory factor 1.

\section{Author contributions}

The authors listed below gave the following contributions. SAH and HGS designed the study. SAH, TY, WJL, JSH, JH, and DSL performed experiments. KSP, DSL, SGH, and CHL assisted in critiquing, editing, and refining the manuscript. SAH and HGS wrote the manuscript. All authors reviewed the manuscript.

\section{CONFLICTS OF INTEREST}

The authors have no conflicts of interest to declare.

\section{FUNDING} 2016.

This work was supported by Konkuk University in

\section{REFERENCES}

1. Giordano Attianese GM, Desvergne B. Integrative and systemic approaches for evaluating PPAR $\beta / \delta$ (PPARD) function. Nucl Recept Signal. 2015;13:e01.

2. Tugwood JD, Issemann I, Anderson RG, Bundell KR, McPheat WL, Green S. The mouse peroxisome proliferator activated receptor recognizes a response element in the $5^{\prime}$ flanking sequence of the rat acyl CoA oxidase gene. EMBO J. 1992;11:433-9.

3. Desvergne B, Wahli W. Peroxisome proliferator-activated receptors: nuclear control of metabolism. Endocr Rev. 1999;20:649-88.

4. Ham SA, Yoo T, Hwang JS, Kang ES, Lee WJ, Paek KS, Park C, Kim JH, Do JT, Lim DS, Seo HG. Ligand-activated PPAR $\delta$ modulates the migration and invasion of melanoma cells by regulating Snail expression. Am J Cancer Res. 2014;4:674-82. 
5. Xu L, Han C, Lim K, Wu T. Cross-talk between peroxisome proliferator-activated receptor delta and cytosolic phospholipase A(2)alpha/ cyclooxygenase-2/prostaglandin $\mathrm{E}(2)$ signaling pathways in human hepatocellular carcinoma cells. Cancer Res. 2006;66:11859-68.

6. Gupta RA, Wang D, Katkuri S, Wang H, Dey SK, DuBois $\mathrm{RN}$. Activation of nuclear hormone receptor peroxisome proliferator-activated receptor-delta accelerates intestinal adenoma growth. Nat Med. 2004;10:245-7.

7. Stephen RL, Gustafsson MC, Jarvis M, Tatoud R, Marshall BR, Knight D, Ehrenborg E, Harris AL, Wolf CR, Palmer CN. Activation of peroxisome proliferator-activated receptor delta stimulates the proliferation of human breast and prostate cancer cell lines. Cancer Res. 2004;64:3162-70.

8. Yuan H, Lu J, Xiao J, Upadhyay G, Umans R, Kallakury B, Yin Y, Fant ME, Kopelovich L, Glazer RI. PPAR $\delta$ induces estrogen receptor-positive mammary neoplasia through an inflammatory and metabolic phenotype linked to mTOR activation. Cancer Res. 2013;73:4349-61.

9. Pollock CB, Yin Y, Yuan H, Zeng X, King S, Li X, Kopelovich L, Albanese C, Glazer RI. PPAR $\delta$ activation acts cooperatively with 3-phosphoinositide-dependent protein kinase- 1 to enhance mammary tumorigenesis. PLoS One. 2011;6:e16215.

10. Bility MT, Zhu B, Kang BH, Gonzalez FJ, Peters JM. Ligand activation of peroxisome proliferator-activated receptor-beta/delta and inhibition of cyclooxygenase-2 enhances inhibition of skin tumorigenesis. Toxicol Sci. 2010;113:27-36.

11. Marin HE, Peraza MA, Billin AN, Willson TM, Ward JM, Kennett MJ, Gonzalez FJ, Peters JM. Ligand activation of peroxisome proliferator-activated receptor beta inhibits colon carcinogenesis. Cancer Res. 2006;66:4394-401.

12. Fukumoto K, Yano Y, Virgona N, Hagiwara H, Sato H, Senba H, Suzuki K, Asano R, Yamada K, Yano T. Peroxisome proliferator-activated receptor delta as a molecular target to regulate lung cancer cell growth. FEBS Lett. 2005;579:3829-36.

13. Yao PL, Morales JL, Zhu B, Kang BH, Gonzalez FJ, Peters JM. Activation of peroxisome proliferator-activated receptor- $\beta / \delta$ (PPAR- $\beta / \delta$ ) inhibits human breast cancer cell line tumorigenicity. Mol Cancer Ther. 2014;13:1008-17.

14. Girroir EE, Hollingshead HE, Billin AN, Willson TM, Robertson GP, Sharma AK, Amin S, Gonzalez FJ, Peters JM. Peroxisome proliferator-activated receptorbeta/delta (PPARbeta/delta) ligands inhibit growth of UACC903 and MCF7 human cancer cell lines. Toxicology. 2008;243:236-43.

15. Lawler J. Thrombospondin-1 as an endogenous inhibitor of angiogenesis and tumor growth. J Cell Mol Med. 2002;6:1-12.

16. John AS, Rothman VL, Tuszynski GP. Thrombospondin-1 (TSP-1) stimulates expression of integrin alpha6 in human breast carcinoma cells: a downstream modulator of TSP-1-induced cellular adhesion. J Oncol. 2010;2010:645376.

17. Rofstad EK, Graff BA. Thrombospondin-1-mediated metastasis suppression by the primary tumor in human melanoma xenografts. J Invest Dermatol. 2001;117:1042-9.

18. Jayachandran A, Anaka M, Prithviraj P, Hudson C, McKeown SJ, Lo PH, Vella LJ, Goding CR, Cebon J, Behren A. Thrombospondin 1 promotes an aggressive phenotype through epithelial-to-mesenchymal transition in human melanoma. Oncotarget. 2014;5:5782-97. https://doi. org/10.18632/oncotarget.2164.

19. Wang TN, Qian X, Granick MS, Solomon MP, Rothman VL, Berger DH, Tuszynski GP. Thrombospondin-1 (TSP-1) promotes the invasive properties of human breast cancer. J Surg Res. 1996;63:39-43.

20. Yee KO, Connolly CM, Duquette M, Kazerounian S, Washington R, Lawler J. The effect of thrombospondin-1 on breast cancer metastasis. Breast Cancer Res Treat. 2009;114:85-96.

21. Lee NV, Sato M, Annis DS, Loo JA, Wu L, Mosher DF, Iruela-Arispe ML. ADAMTS1 mediates the release of antiangiogenic polypeptides from TSP1 and 2. EMBO J. 2006;25:5270-83.

22. Cal S, López-Otín C. ADAMTS proteases and cancer. Matrix Biol. 2015;44-46:77-85.

23. Rocks N, Paulissen G, Quesada-Calvo F, Munaut C, Gonzalez ML, Gueders M, Hacha J, Gilles C, Foidart JM, Noel A, Cataldo DD. ADAMTS-1 metalloproteinase promotes tumor development through the induction of a stromal reaction in vivo. Cancer Res. 2008;68:9541-50.

24. Masui T, Hosotani R, Tsuji S, Miyamoto Y, Yasuda S, Ida J, Nakajima S, Kawaguchi M, Kobayashi H, Koizumi M. Expression of METH-1 and METH-2 in pancreatic cancer. Clin Cancer Res. 2001;7:3437-43.

25. Porter S, Scott SD, Sassoon EM, Williams MR, Jones JL, Girling AC, Ball RY, Edwards DR. Dysregulated expression of adamalysin-thrombospondin genes in human breast carcinoma. Clin Cancer Res. 2004;10:2429-40.

26. Freitas VM, do Amaral JB, Silva TA, Santos ES, Mangone FR, Pinheiro Jde J, Jaeger RG, Nagai MA, MachadoSantelli GM. Decreased expression of ADAMTS-1 in human breast tumors stimulates migration and invasion. Mol Cancer. 2013;12:2.

27. Shearer BG, Steger DJ, Way JM, Stanley TB, Lobe DC, Grillot DA, Iannone MA, Lazar MA, Willson TM, Billin AN. Identification and characterization of a selective peroxisome proliferator-activated receptor beta/delta (NR1C2) antagonist. Mol Endocrinol. 2008;22:523-9.

28. Moon Y, Bottone FG Jr, McEntee MF, Eling TE. Suppression of tumor cell invasion by cyclooxygenase inhibitors is mediated by thrombospondin-1 via the early growth response gene Egr-1. Mol Cancer Ther. 2005;4:1551-8. 
29. Sid B, Langlois B, Sartelet H, Bellon G, Dedieu S, Martiny L. Thrombospondin-1 enhances human thyroid carcinoma cell invasion through urokinase activity. Int J Biochem Cell Biol. 2008;40:1890-900.

30. Radziwon-Balicka A, Santos-Martinez MJ, Corbalan JJ, O'Sullivan S, Treumann A, Gilmer JF, Radomski MW, Medina C. Mechanisms of platelet-stimulated colon cancerinvasion: role of clusterin and thrombospondin 1 in regulation of the P38MAPK-MMP-9 pathway. Carcinogenesis. 2014;35:324-32.

31. Coleman JD, Thompson JT, Smith RW, Prokopczyk B, Vanden Heuvel JP. Role of peroxisome proliferatoractivated receptor $\beta / \delta$ and B-cell lymphoma- 6 in regulation of genes involved in metastasis and migration in pancreatic cancer cells. PPAR Res. 2013;2013:121956.

32. Yin Y, Russell RG, Dettin LE, Bai R, Wei ZL, Kozikowski AP, Kopelovich L, Glazer RI. Peroxisome proliferatoractivated receptor delta and gamma agonists differentially alter tumor differentiation and progression during mammary carcinogenesis. Cancer Res. 2005;65:3950-7.

33. Roberts DD. Regulation of tumor growth and metastasis by thrombospondin-1. FASEB J. 1996;10:1183-91.

34. Albo D, Shinohara T, Tuszynski GP. Up-regulation of matrix metalloproteinase 9 by thrombospondin 1 in gastric cancer. J Surg Res. 2002;108:51-60.

35. Green DE, Kang BY, Murphy TC, Hart CM. Peroxisome proliferator-activated receptor gamma (PPAR $\gamma)$ regulates thrombospondin-1 and Nox4 expression in hypoxia-induced human pulmonary artery smooth muscle cell proliferation. Pulm Circ. 2012;2:483-91.
36. Lu X, Wang Q, Hu G, Van Poznak C, Fleisher M, Reiss M, Massagué J, Kang Y. ADAMTS1 and MMP1 proteolytically engage EGF-like ligands in an osteolytic signaling cascade for bone metastasis. Genes Dev. 2009;23:1882-94.

37. Tyan SW, Hsu CH, Peng KL, Chen CC, Kuo WH, Lee EY, Shew JY, Chang KJ, Juan LJ, Lee WH. Breast cancer cells induce stromal fibroblasts to secrete ADAMTS1 for cancer invasion through an epigenetic change. PLoS One. 2012;7:e35128.

38. Lee YJ, Koch M, Karl D, Torres-Collado AX, Fernando NT, Rothrock C, Kuruppu D, Ryeom S, Iruela-Arispe ML, Yoon SS. Variable inhibition of thrombospondin 1 against liver and lung metastases through differential activation of metalloproteinase ADAMTS1. Cancer Res. 2010;70:948-56.

39. Nakamura K, Hirohata S, Murakami T, Miyoshi T, Demircan K, Oohashi T, Ogawa H, Koten K, Toeda K, Kusachi S, Ninomiya Y, Shiratori Y. Dynamic induction of ADAMTS1 gene in the early phase of acute myocardial infarction. J Biochem. 2004;136:439-46.

40. Turkoglu SA, Kockar F. SP1 and USF differentially regulate ADAMTS1 gene expression under normoxic and hypoxic conditions in hepatoma cells. Gene. 2016;575:48-57.

41. Ham SA, Kim HJ, Kim HJ, Kang ES, Eun SY, Kim GH, Park MH, Woo IS, Kim HJ, Chang KC, Lee JH, Seo HG. PPARdelta promotes wound healing by up-regulating TGFbeta1-dependent or -independent expression of extracellular matrix proteins. J Cell Mol Med. 2010;14:1747-59. 